\section{JURNAL EKONOMI EFEKTIF}

ISSN : $2622-8882$, E-ISSN : 2622-9935

Jurnal Ekonomi Efektif, Vol. 2, No. 4, Juli 2020

@Prodi Manajemen Fakultas Ekonomi Universitas

Pamulang

\title{
PENGARUH EFIKASI DIRI TERHADAP KEPUASAN KERJA KARYAWAN PADA PDAM KOTA BANDUNG
}

\author{
Vip Paramarta \\ Universitas Sangga Buana, Bandung, Jawa Barat, Indonesia \\ *vip@usbypkp.ac.id
}

\begin{abstract}
ABSTRAK
Penelitian ini bertujuan untuk mengetahui pengaruh efikasi diri terhadap kepuasan kerja karyawan pada PDAM Kota Bandung. Metode yang digunakan adalah explanatory research dengan sampel sebanyak 93 responden. Teknik analisis menggunakan analisis statistik dengan pengujian regresi, korelasi, determinasi dan uji hipotesis. Hasil penelitian ini variabel efikasi diri diperoleh nilai rata-rata skor sebesar 3,423 dengan kriteria baik. Variabel kepuasan kerja karyawan diperoleh nilai rata-rata skor sebesar 3,849 dengan kriteria baik. Efikasi diri berpengaruh positif dan signifikan terhadap kepuasan kerja karyawan dengan nilai persamaan regresi $\mathrm{Y}=9,259+0,854 \mathrm{X}$, dan nilai koefisien korelasi 0,775 atau memiliki tingkat hubungan yang kuat dengan nilai determinasi $60,0 \%$. Uji hipotesis diperoleh signifikansi $0,000<0,05$.
\end{abstract}

\section{Kata Kunci: Efikasi Diri, Kepuasan Kerja Karyawan.}

\section{ABSTRACT}

This study aims to determine the effect of self-efficacy on employee job satisfaction at PDAM Kota Bandung. The method used is explanatory research with a sample of 93 respondents. The analysis technique uses statistical analysis with regression testing, correlation, determination and hypothesis testing. The results of this study, the self-efficacy variable obtained an average score of 3,423 with good criteria. Employee job satisfaction variable obtained an average score of 3.849 with good criteria. Self-efficacy has a positive and significant effect on employee job satisfaction with a regression equation value of $Y=9.259+$ $0.854 X$, and a correlation coefficient value of 0.775 or has a strong level of relationship with a determination value of $60.0 \%$. Hypothesis testing obtained a significance of $0.000<0.05$.

Keywords: Self-Efficacy, Employee Job Satisfaction. 


\section{PENDAHULUAN}

\section{A. Latar Belakang Masalah}

Perkembangan ekonomi pada era globalisasi banyak dipengaruhi oleh persaingan bisnis yang semakin ketat. Banyak tantangan yang harus dihadapi oleh perusahaan. Perusahaan perlu menjaga kualitas sumber daya manusia (SDM) mereka untuk tetap bersaing agar perusahaan mampu terus maju dan berkembang. Karyawan adalah salah satu faktor penting karena mereka adalah sebuah aset yang dimiliki perusahaan untuk menentukan sukses atau tidak perusahaan tersebut.

Kepuasan kerja menjadi kunci penting untuk tetap menjaga kualitas sumber daya manusia (SDM) dalam perusahaan. Pada akhirnya dengan terciptanya kepuasan kerja diharapkan karyawan mampu meningkatkan kualitas mereka untuk masa yang akan datang. Dalam pelaksanaan pencapaian tujuan tersebut bukanlah hal yang mudah. Faktor yang mendorong kepuasan kerja karyawan adalah dengan mengukur efikasi diri dan memberi motivasi

Efikasi diri dan motivasi merupakan suatu dorongan yang dapat mempengaruhi kepuasan kerja, dalam hal ini kepuasan kerja akan semakin baik. Dengan efikasi diri dan motivasi dapat meningkatkan kepuasan kerja. Menurut (Sutrisno, 2009:74). kepuasan kerja adalah gambaran dari sebuah sikap seorang individu akan pekerjaan yang akan memiliki hubungan dengan kerjasama yang dimiliki antar sesama karyawan ataupun imbalan yang akan diterima. hal tersebut dapat dikatakan menyangkut adanya faktor fisik dan psikologis yang dimiliki oleh karyawan. Bandura (1997) menjelaskan efikasi diri sebagai kemampuan akan keyakinan yang dimiliki individu untuk dapat mengorganisasi dan melaksanakan serangkaian tindakan yang dianggap perlu untuk mencapai suatu hasil yang diinginkan.

Mishra et al (2016) menyatakan bahwa peningkatan efikasi diri kemungkinan akan mendorong tumbuhnya kepuasan kerja. Sehingga kepercayaan diri yang ada karena beban tanggung jawab yang harus diselesaikan. Hasil penelitian sejalan dengan yang dipaparkan oleh Mishra et al. (2016), Pahi et al (2016) dan Karabiyik et al (2014) menyatakan bahwa efikasi diri berpengaruh postif terhadap kepuasan kerja. Namun hasil penelitian Seyithan Demirdag (2015) menunjukkan tidak ada pengaruh yang signifikan efikasi diri terhadap kepuasan kerja. Menurut Ersanl (2015) dimana dengan tingginya efikasi diri yang dimiliki seseorang akan membuat seseorang termotivasi dan akan mendapatkan kekuatan pendorong untuk dapat mengejar tujuan dan mengatasi hambatan yang dimiliki.

Berdasarkan latar belakang dan fenemona yang ada, telah ditemukan kesenjangan penelitian (research gap), maka hal tersebut dapat di jadikan dasar untuk penulis melaksanakan penelitian tentang "pengaruh efikasi diri terhadap kepuasan kerja karyawan pada PDAM Kota Bandung"

\section{B. Rumusan Masalah}

1. Bagaimana efikasi diri pada PDAM Kota Bandung?.

2. Bagaimana kepuasan kerja karyawan pada PDAM Kota Bandung ?.

3. Adakah pengaruh antara efikasi diri terhadap kepuasan kerja karyawan pada PDAM Kota Bandung?.

\section{Tujuan Penelitian}

1. Untuk mengetahui kondisi efikasi diri pada PDAM Kota Bandung.

2. Untuk mengetahui kondisi kepuasan kerja karyawan pada PDAM Kota Bandung.

3. Untuk mengetahui pengaruh efikasi diri terhadap kepuasan kerja karyawan pada PDAM Kota Bandung. 


\section{TINJAUAN PUSTAKA}

\section{Efikasi diri}

Menurut Bandura (1997) definisi efikasi diri sebagai kemampuan akan keyakinan yang dimiliki individu untuk dapat mengorganisasi dan melaksanakan serangkaian tindakan yang dianggap perlu untuk mencapai suatu hasil yang diinginkan. Teori efikasi diri merupakan cabang dari Social Cognitive Theory. Social Cognitive Theory menyoroti pertemuan yang kebetulan dan kejadian yang tak terduga meskipun kejadian tersebut tidak serta merta mengubah jalan hidup manusia. Beberapa asumsi awal dan mendasar dari Social Cognitive Theory yang dikembangkan oleh Bandura adalah Learning Theory (teori pembelajaran) yang berasumsi bahwa manusia cukup fleksibel dan mampu mempelajari beragam kecakapan bersikap maupun berprilaku dan bahwa titik pembelajaran terbaik dari itu semua adalah pengalaman-pengalaman tak terduga Bandura (1997).

\section{Kepuasan Kerja Karyawan}

Menurut Sutrisno (2019:73) "Kepuasan keja menjadi masalah yang cukup menarik dan penting, karena terbukti besar manfaatnya bagi kepentingan individu, industri dan masyarakat. Bagi individu, penelitian tentang sebab-sebab dan sumber-sumber kepuasan kerja memungkinkan timbulnya usaha-usaha peningkatan kebahagiaan hidup mereka. Bagi industri, penelitian mengenai kepuasan kerja dilakukan dalam rangka usaha peningkatan produksi dan pengaruh biaya melalui perbaikan sikap dan tingkah laku karyawannya. Selanjutnya, masyarakat tentu akan menikmati hasil kapasitas maksimum dari industri serta naiknya nilai manusia di dalam konteks pekerjaan."

\section{METODE PENELITIAN}

1. Populasi

Populasi dalam penelitian ini berjumlah 93 responden $\mathrm{P}$

\section{Sampel}

Teknik pengambilan sampling dalam penelitian ini adalah sampel jenuh, dimana semua anggota populasi dijadikan sebagai sampel. Dengan demikian sampel dalam penelitian ini sampel yang digunakan berjumlah 93 responden.

\section{Jenis Penelitian}

Jenis penelitian yang dipakai adalah asosiatif, dimana tujuannya adalah untuk mengetahui atau mencari keterhubungan antara variabel independen terhadap variabel dependennya

\section{Metode Analisis Data}

Dalam menganalisis data digunakan uji validitas, uji reliabilitas, analisis regresi linier sederhana, analisis koefisien korelasi, analisis koefisien determinasi dan pengujian hipotesis.

\section{HASIL PENELITIAN}

\section{Analisis Deskriptif}

Pada pengujian ini digunakan untuk mengetahui skor minimum dan maksimum skor tertinggi, ratting score dan standar deviasi dari masing-masing variabel. Adapun hasilnya sebagai berikut:

Tabel 1. Hasil Analisis Descriptive Statistics

Descriptive Statistics 


\begin{tabular}{lr|r|r|r|r} 
& N & Minimum & Maximum & Mean & Std. Deviation \\
\hline Efikasi diri (X) & 93 & 28 & 44 & 34.23 & 3.935 \\
\hline Kepuasan kerja Karyawan (Y) & 93 & 29 & 49 & 38.49 & 4.338 \\
\hline Valid N (listwise) & 93 & & & & \\
\hline
\end{tabular}

Efikasi diri diperoleh varians minimum sebesar 28 dan varians maximum 44 dengan ratting score sebesar 3,423 dengan standar deviasi 3,935. Skor ini termasuk pada rentang sakala 3,40 - 4,19 dengan kriteria baik atau setuju.

Kepuasan kerja karyawan diperoleh varians minimum sebesar 29 dan varians maximum 49 dengan ratting score sebesar 3,849 dengan standar deviasi 4,338. Skor ini termasuk pada rentang sakala 3,40 - 4,19 dengan kriteria baik atau setuju.

\section{Analisis Kuantitatif.}

Pada analisis ini dimaksudkan untuk mengetahui pengaruh variabel independen terhadap variabel dependen. Adapun hasil pengujian sebagai berikut:

\section{a. Analisis Regresi Linier Sederhana}

Uji regresi ini dimaksudkan untuk mengetahui perubahan variabel dependen jika variabel independen mengalami perubahan. Adapun hasil pengujiannya sebagai berikut:

Tabel 2. Hasil Pengujian Regresi Linier Sederhana

\begin{tabular}{|c|c|c|c|c|c|c|}
\hline \multirow{2}{*}{\multicolumn{2}{|c|}{ Model }} & \multicolumn{2}{|c|}{$\begin{array}{l}\text { Coefficients }^{\text {a }} \\
\text { Unstandardized } \\
\text { Coefficients }\end{array}$} & \multirow{2}{*}{$\begin{array}{l}\text { Standardized } \\
\text { Coefficients } \\
\text { Beta }\end{array}$} & \multirow[b]{2}{*}{$\mathrm{t}$} & \multirow[b]{2}{*}{ Sig. } \\
\hline & & B & Std. Error & & & \\
\hline & (Constant) & 9.259 & 2.517 & & 3.678 & .000 \\
\hline & Efikasi diri (X) & .854 & .073 & .775 & 11.690 & .000 \\
\hline
\end{tabular}

a. Dependent Variable: Kepuasan kerja Karyawan (Y)

Berdasarkan hasil pengujian pada tabel di atas, diperoleh persamaan regresi $\mathrm{Y}=$ $9,259+0,854 X$. Dari persamaan tersebut dijelaskan sebagai berikut:

1) Konstanta sebesar 9,259 diartikan jika efikasi diri tidak ada, maka telah terdapat nilai kepuasan kerja karyawan sebesar 9,259 point.

2) Koefisien regresi efikasi diri sebesar 0,854, angka ini positif artinya setiap ada peningkatan efikasi diri sebesar 0,854 point maka kepuasan kerja karyawan juga akan mengalami peningkatan sebesar 0,854 point.

\section{b. Analisis Koefisien Korelasi}

Analisis koefisien korelasi dimaksudkan untuk mengetahui tingkat kekuatan hubungan dari variabel independen terhadap variabel dependen. Adapun hasil pengujian sebagai berikut:

Tabel 3. Hasil Pengujian Koefisien Korelasi Efikasi diri Terhadap Kepuasan kerja Karyawan.

\begin{tabular}{|c|c|c|c|}
\hline \multicolumn{4}{|c|}{ Correlations $^{b}$} \\
\hline & & Efikasi diri $(\mathrm{X})$ & $\begin{array}{c}\text { Kepuasan kerja } \\
\text { Karyawan }(Y)\end{array}$ \\
\hline \multirow[t]{2}{*}{ Efikasi diri (X) } & Pearson Correlation & 1 & $.775^{\star *}$ \\
\hline & Sig. (2-tailed) & & .000 \\
\hline \multirow{2}{*}{$\begin{array}{l}\text { Kepuasan kerja } \\
\text { Karyawan }(Y)\end{array}$} & Pearson Correlation & $.775^{\star *}$ & 1 \\
\hline & Sig. (2-tailed) & .000 & \\
\hline
\end{tabular}

Berdasarkan hasil pengujian diperoleh nilai korelasi sebesar 0,775 artinya efikasi diri memiliki hubungan yang kuat terhadap kepuasan kerja karyawan. 


\section{KESIMPULAN DAN SARAN}

\section{Kesimpulan}

a. Variabel efikasi diri diperoleh ratting score sebesar 3,423 berada di rentang skala 3,40 4,19 dengan kriteria baik atau setuju.

b. Variabel kepuasan kerja karyawan diperoleh ratting score sebesar 3,849 berada di rentang skala 3,40 - 4,19 dengan kriteria baik atau setuju.

c. Efikasi diri berpengaruh signifikan terhadap kepuasan kerja karyawan dengan persamaan regresi $\mathrm{Y}=9,259+0,854 \mathrm{X}$, nilai korelasi sebesar 0,775 atau kuat dan kontribusi pengaruh sebesar $60,0 \%$ sedangkan sisanya sebesar $40,0 \%$ dipengaruhi faktor lain. Uji hipotesis diperoleh nilai $t$ hitung $>t$ tabel atau $(11,690 \%>1,989)$.

\section{Saran}

a. Perusahaan harus menegakkan peraturan dengan baik sesuai dengan ketentuan yang berlaku guna menjamin karyawan diperlakukan dengan adil.

b. Perusahaan harus selalu memberikan semangat dan apresiasi yang layak untuk memastikan karyawan memiliki semangat kerja yang tinggi.

c. Kepuasan kerja perusahaan dapat ditingkatkan dengan memberdayakan karyawan dengan menegakkan peraturan yang baik dan pemberian motivasi yang lebih intens lagi.

\section{DAFTAR PUSTAKA}

Abdullah, M (2014) Manajemen dan Evaluasi Kepuasan kerja Karyawan, Yogyakarta: Penerbit Aswaja Pressindo.

Algifari. (2015). “Analisis Regresi untuk Bisnis dan Ekonomi”. Yogyakarta: BPFE.

Arikunto, Suharsimi (2014). "Prosedur Penelitian Suatu Pendekatan Praktek". Jakarta: Rineka Cipta.

Bangun, Wilson. 2012. "Manajemen Sumber Daya Manusia”. Jakarta: Erlangga

Bejo Siswanto (2013) Manajemen Tenaga Kerja Rancangan dalam Pendayagunaan dan Pengembangan Unsur Tenaga Kerja", Bandung: Sinar Baru.

Dessler, G. (2006.) Manajemen Sumber Daya Manusia (Jilid II). Jakarta: Indeks.

Edi Sutrisno (2016). Manajemen Sumber Daya Manusia. Jakarta: Prenadamedia Group.

Edi Sutrisno (2016). Manajemen Sumber Daya Manusia. Jakarta: Prenadamedia Group.

George Terry R \& Rue, Leslie W. Rue (2016) Dasar-Dasar Manajemen, Jakarta Bumi Aksara. Gerry Dessler (2016) Human Resources Management, Prenticehall, London: International Inc. Handoko (2016) Manajemen Personalia dan Sumberdaya Manusia. Yogyakarta: BPFE.

Hasibuan, Malayu S.P. (2016). Manajemen Sumber Daya Manusia. Edisi Revisi. Jakarta: PT Bumi Aksara.

Ilham, D. (2014). Implementasi Nilai-Nilai Keagamaan pada Mata Pelajaran Umum dalam Upaya Peningkatan Akhlak Peserta Didik di MAN Malili Kabupaten Luwu

Timur (Doctoral dissertation, STAIN/IAIN Palopo).

Ilham, D. (2019). Implementing Local Wisdom Values in Bride and Groom Course at KUA Bara SubDistrict, Palopo City. Jurnal Konsepsi, 8(1), 1-9.

Ilham, D. (2019). Menggagas Pendidikan Nilai dalam Sistem Pendidikan

Nasional. Didaktika: Jurnal Kependidikan, 8(3), 109-122.

Imam Ghozali (2017). “Aplikasi Analisis Multivariate Dengan Program SPSS”. Edisi Kelima. Semarang: Badan Penerbit Undip.

Istijanto (2014) “Riset Sumber Daya Manusia”. Jakarta: PT. Gramedia Pustaka 
Kharis, Ismu Fadli (2011). "Studi Mengenai Impulse Buying dalam Penjualan Online". Semarang : Skripsi Universitas Diponegoro

Lismiatun, L. (2018). Pengaruh Gaya Kepemimpinan Transformasional Terhadap Organizational Citizenship Behavior Dan Komitmen Organisasi Dengan Kepuasan Kerja Sebagai Peran Mediasinya (Studi Pada Karyawan PT. 3M Mining, Manufacturing, Mineshota Indonesia Departemen Supply Chain Operation). JENIUS (Jurnal Ilmiah Manajemen Sumber Daya Manusia), 1(3).

Luthans Fred (2014) Organizational Behavior, Ney York: McGraw-Hill, New York.

Mangkunegara, Prabu Anwar. (2016). Evaluasi Kepuasan kerja SDM. Cetakan ke tujuh, PT Refika Aditama: Bandung.

Rao, Purba, (2012). "Measuring Consumer Perceptions Through Factor Analysis”, The Asian.

Robbins, P.S, \& Judge, A.T. (2003). Organizational Behavior. Jakarta: Salemba Empat.

Santoso, Singgih (2015). "Menguasai Statistik Multivariat”. Jakarta: PT Elex Media Komputindo.

Sedarmayanti (2016) Manajemen Sumber Daya Manusia, Reformasi Birokrasi dan Manajemen Karyawan Negeri Sipil, Cetakan Kelima, Bandung: PT Refika Aditama.

Sudjana (2014) "Metode Statistika”, Bandung: Tarsido.

Sugiyono (2017), "Metode Penelitian Administrasi : dilengkapi dengan Metode $R \& D$ ”. Bandung: Alfabeta.

Sunarsi, D. (2019). Penerapan MSDM Strategis Dalam Upaya Meningkatkan Kemampuan Organisasi dalam menyongsong Revolusi 4.0. Jurnal Ilmiah MEA (Manajemen, Ekonomi, \& Akuntansi), 3(1), 221-233. https://doi.org/10.31955/mea.vol3.iss1.pp221233

Veithzal Rivai (2015) Manajemen Sumber Daya Manusia Untuk Perusahaan, Jakarta: Raja Grafindo Persada.

Wibowo (2015) Manajemen Kepuasan kerja, Jakarta: PT. Raja Grafindo Persada.

Yuangga, K. D., \& Sunarsi, D. (2018). The Influence of Procrastination and Low Time Management on Student Self Efficacy (at MA Soebono Mantofani). PINISI Discretion Review, 2(1), 85-92. 